\title{
Perancangan School Management System Pada Website Sekolah Menengah Kejuruan Negeri 1 Medan Dengan Menggunakan Model View Controller
}

\author{
Diki Irwansyah $^{* 1}$, Iwan Purnama ${ }^{2}$, Gomal Juni Yandris ${ }^{3}$ \\ ${ }^{1,2,3}$ Universitas Labuhan Batu, Rantau Prapat,Indonesia \\ Email : dikyleo@gmail.com ${ }^{* 1}$, iwanpurnama2014@gmail.com² silaengomal@yahoo.com $^{3}$
}

\begin{abstract}
Abstrak
Dengan perkembangan teknologi yang semakin pesat, sarana dan prasarana pendidikan pun harus mengikutinya, salah satunya dengan media komputerisasi yaitu internet. Dengan internet dimana siswa maupun guru dapat mengakses ilmu pengetahuan dan informasi kapan saja dan dimana saja. Banyak sekali manfaat dari internet. Salah satunya adalah pembuatan sistem berbasis web, sistem ini akan menampilkan informasi mengenai hal-hal sesuai dengan apa yang dikehendaki oleh pembuat. Website merupakan halaman situs sistem informasi yang dapat diakses secara cepat. website ini didasari adanya perkembangan teknologi informasi dan komunikasi. Melalui perkembangan teknologi informasi, tercipta jaringan antar komputer yang saling berkaitan. Jaringan yang dikenal dengan istilah internet secara terus-menerus menjadi pesan-pesan elektronik, termasuk e-mail, transmisi file, dan komunikasi dua arah antar individu atau komputer. Model View Controller atau MVC adalah sebuah metode untuk membuat sebuah aplikasi dengan memisahkan data (Model) dari tampilan (View) dan cara bagaiman memprosesnya (Controller). Dalam implementasinya kebanyakan Framework dalam aplikasi website adalah berbasis arsitektur MVC.
\end{abstract}

Kata kunci-Website, Model View Controller

\begin{abstract}
With the rapid development of technology, educational facilities and infrastructure must follow, one of them with computerized media namely the internet. With the internet where students and teachers can access knowledge and information anytime and anywhere. Lots of benefits from the internet. One of them is the creation of a web-based system, the system will display information about things in accordance with what is desired by the manufacturer. Websites are pages of information system sites that can be accessed quickly. this website is based on the development of information and communication technology. Through the development of information technology, created a network of interconnected computers. Networks known as the Internet constantly become electronic messages, including e-mail, file transmission, and two-way communication between individuals or computers. Model View Controller or MVC is a method for creating an application by separating data (Model) from view (View) and how to process it (Controller). In most implementations Framework in the website application is based on MVC architecture.
\end{abstract}

Keywords-Website, Model View Controller

\section{PENDAHULUAN}

Dalam rangka pembangunan sumber daya manusia, bidang pendidikan merupakan sarana dan wahana yang sangat baik dalam pembinaan sumber daya manusia. Oleh karena itu pendidikan perlu mendapat perhatian yang lebih serius baik itu oleh pemerintah, keluarga maupun pengelola pendidikan khususnya. Dengan perkembangan teknologi yang semakin pesat, sarana dan prasarana pendidikan pun harus mengikutinya, salah satunya dengan media komputerisasi yaitu internet. Dengan internet dimana 
siswa maupun guru dapat mengakses ilmu pengetahuan dan informasi kapan saja dan dimana saja(Sihombing et al., 2020). Banyak sekali manfaat dari internet. Salah satunya adalah pembuatan sistem berbasis web, sistem ini akan menampilkan informasi mengenai hal-hal sesuai dengan apa yang dikehendaki oleh pembuat. Sebuah sistem informasi yang baik tentunya mampu menjalankan semua hal yang berkaitan dengan penyelenggaraan hal-hal spesifik. Semua komponen dipermudah dengan adanya sistem ini. Untuk membuat sebuah program aplikasi yang baik, pengolahan data merupakan kunci utama untuk mencapai kesempurnaan. Dengan pengolahan data yang baik maka kita dapat dengan mudah mengakses data yang dibutuhkan(Banjarnahor \& Lim, 2020).

Selama ini di SMK Negeri 1 Medan informasi belum mengoptimalkan sistem basis data berbasis webini dengan baik. Dalam penginputan nilai siswa juga masih secara manual yang dilakukan oleh masing-masing guru wali kelas. Pada saat masuk tahun ajaran baru, penerimaan siswa baru dilakukan juga dengan cara manual yaitu dengan cara siswa datang ke sekolah kemudian mengisi formulir pendaftaran. Sehingga bagi pendaftar yang bertempat tinggal jauh dari lokasi sekolah akan membuang banyak waktu untuk mengantri dan mengisi formulir pendaftaran(Sitanggang et al., 2020).

Pada penelitian ini penulis akan menggunakan Model View Controller (MVC). Model View Controller adalah sebuah metode untuk membuat aplikasi dengan memisahkan data (model) dari tampilan (view) dan cara bagaimana memprosesnya (controller)(Sekip et al., 2020). Model view controller memisahkan pengembangan aplikasi berdasarkan komponen utama yang membangun sebuah aplikasi seperti manipulasi data, antarmuka pengguna dan bagian yang menjadi kontrol dalam sebuah aplikasi web(Hardiansyah, 2018). Pada perancangan school management system web sekolah ini, khususnya untuk pendaftaran online dan penginputan nilai siswa model MVC ini bisa untuk digunakan(Simarmata et al., 2018). Dengan model mewakili struktur data pendaftar dan nilai siswa yang berisi fungsi-fungsi untuk membantu seseorang dalam pengelolaan basis data seperti memasukkan data ke basis data(Nababan et al., 2020)pembaharuan data dan lai-lain.View adalah bagian yang mengatur tampilan output ke pengguna yang disebut juga sebagai halaman web(Andaru, 2018). Dan controller merupakan bagian yang menjembatani model dan view yang berisi perintah-perintah dan berfungsi untuk memproses suatu data lalu mengirimkannya ke halaman web.

\section{METODE PENELITIAN}

Dalam proses pembuatan laporan Penelitian ini penulis melakukan penerapan metode penelitian dalam memperoleh data-data yang dibutuhkan sehingga penyusunan ini dapat diselesaikan dengan baik. Adapun metode penelitian yang penulis lakukan adalah dengan cara sebagai berikut :

1. Tahap pengumpulan data

Pada tahap ini penulis mengumpulkan data dari berbagai sumber, seperti buku, jurnal, dan sumbersumber lainnya.

2. Tahap analisa sistem

Pada tahap ini penulis mendefenisikan kembali masalah, memahami sistem yang ada, membuat logika dan penyelesaiannya.

3. Tahap pembuatan sistem

Dalam tahap pembuatan sistem ini penulis mencoba menyelesaikan antara perencanaan sistem dengan kenyataan dalam praktek.

4. Tahap uji coba program

Pada tahap uji coba program ini penulis mencoba melakukan pengujian terhadap semua kemungkinan bacaan yang ada dalam batasan masalah, apakah sudah sesuai harapan atau harus dilakukan pembenahan.

5. Tahap pembuatan laporan hasil penelitian

Pada tahap ini penulis menyimpulkan hasil penelitian yang dilakukan dan memberikan saran untuk penelitian berikutnya. 


\section{A. Perancangan}

\section{HASIL DAN PEMBAHASAN}

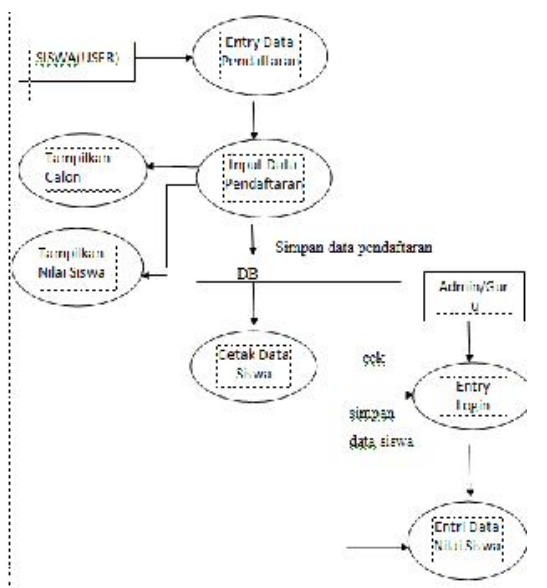

Gambar 3.1 DFD Level 0 Yang Sedang Berjalan

\section{B. Pembahasan}

Pada umumnya dalam pendaftaran siswa baru, pihak sekolah masih menggunakan cara yang manual yaitu calon-calon siswa harus datang langsung ke sekolah tersebut untuk mengisi formulir pendaftaran. Sehingga bagi calon siswa yang mungkin memilki tempat tinggal yang jauh akan banyak menyita waktu. Dalam laporan ini disajikan beberapa sistem yaitu sistem pendaftaran online bagi siswa baru dan sistem penginputan nilai siswa. Sehingga calon-calon siswa baru dapat langsung mengakses alamat website sekolah dan mengisi form pendaftaran yang tersedia pada entry pendaftaran siswa. Sedangkan siswa dapat juga mengakses langsung alamat website sekolah dan melihat nilai dari masing-masing mata pelajaran siswa pada entry nilai siswa.

\section{Perancangan Database Sekolah}

Tabel daftar digunakan untuk membuat laporan mengenai data-data calon siswa yang mendaftar di SMK Negeri 1 Medan.

Tabel 1. Daftar

\begin{tabular}{|c|c|c|}
\hline Field Name & Type & Size \\
\hline ID & Int & 20 \\
\hline Nama & Varchar & - \\
\hline Alamat & Text & 15 \\
\hline Tempat Lahir & Varchar & 15 \\
\hline Tanggal Lahir & Varchar & 20 \\
\hline Sekolah Asal & Varchar & 10 \\
\hline Nun & Int & 20 \\
\hline Nama ortu & Varchar & - \\
\hline Alamat ortu & Text & 15 \\
\hline Pendidikan terakhir & Varchar & 20 \\
\hline Pekerjaan & Varchar & 15 \\
\hline Penghasilan & Int & (1) \\
\hline
\end{tabular}

Tabel nilai digunakan untuk membuat laporan mengenai data nIlai siswa di SMK Negeri 1 Medan. 
Tabel 2. Siswa

\begin{tabular}{|l|l|lc|}
\hline \multicolumn{1}{|c|}{ Field Name } & \multicolumn{1}{c|}{ Type } & \multicolumn{1}{c|}{ Size } \\
\hline Id Siswa & Int & 5 & 15 \\
\hline NISN & Int & 20 \\
\hline Nama & Varchar & 10 \\
\hline Kelas & Varchar & \\
\hline
\end{tabular}

Tabel 3. Nilai

\begin{tabular}{|c|c|c|}
\hline Field Name & Type & Size \\
\hline Id Nilai & Int & 5 \\
\hline Id Siswa & Int & 5 \\
\hline Mata Pelajaran & Varchar & 15 \\
\hline Semester & Varchar & 10 \\
\hline Nilai & Int & 5 \\
\hline
\end{tabular}

\section{Implementasi Sistem}

\section{Tampilan Admin}

Admin adalah seorang yang memiliki kekuasaan penuh terhadap data yang telah dibuat. Beberapa bagian dalam admin adalah sebagai berikut.

1. Tampilan Halaman Login Admin

Tampilan halaman digunakan oleh admin untuk masuk ke halaman admin, administrator harus memasukkan username dan password yang sesuai untuk masuk ke halaman admin, berikut tampilannya.

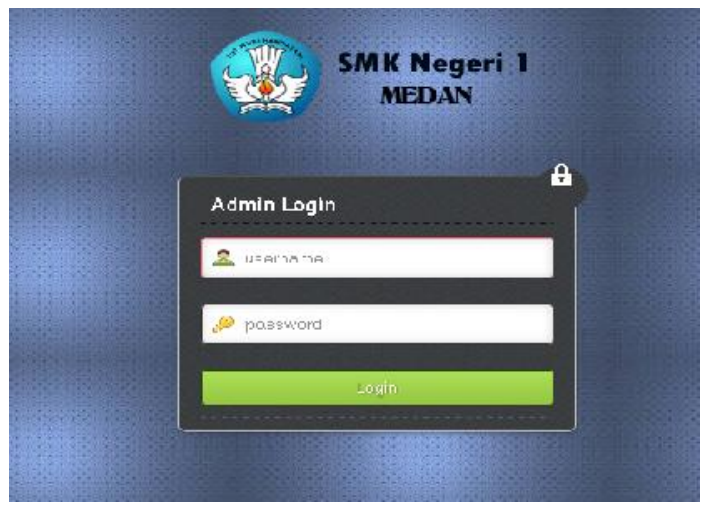

Gambar 1. Halaman Login Admin

2. Tampilan Halaman Admin

Halaman admin muncul ketika username dan password yang dimasukkan sudah benar, berikut tampilannya

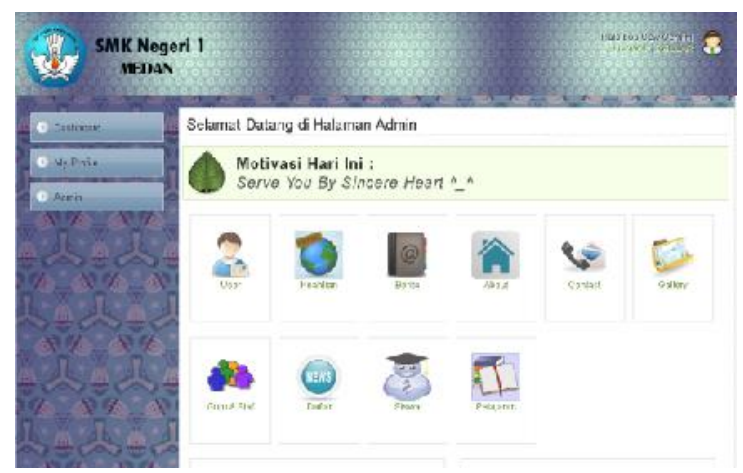

Gambar 2. Halaman Admin 
3. Tampilan Input Admin Halaman Berita

Tampilan input halaman berita digunakan oleh admin untuk menginput data pada halaman berita, berikut tampilannya.

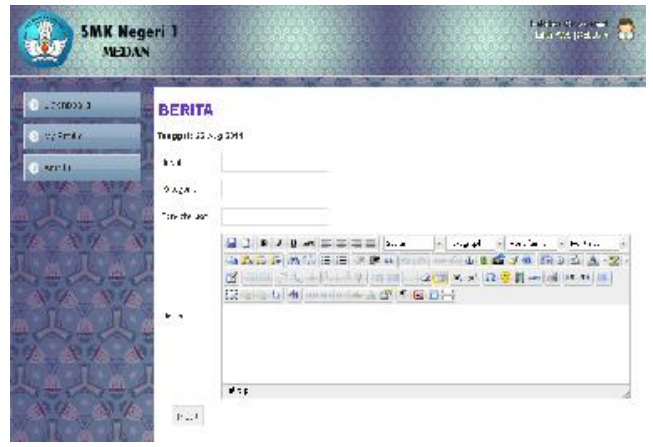

Gambar 3. Tampilan Input Admin Halaman Berita

4. Tampilan Output Admin Halaman Berita

Tampilan output halaman berita digunakan oleh admin untuk menampilkan data pada halaman berita, berikut tampilannya.

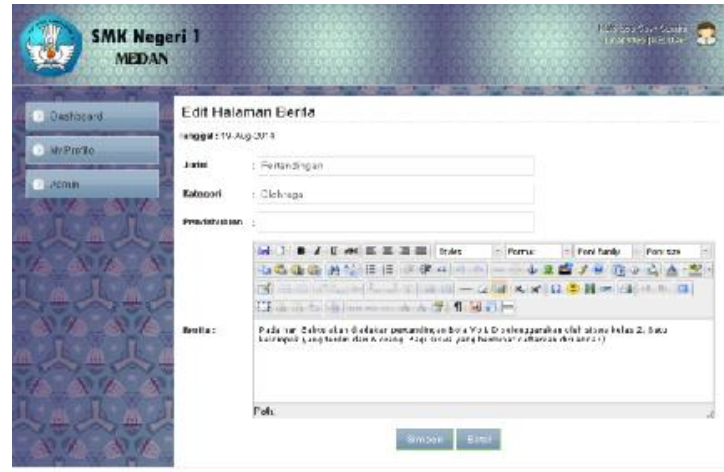

Gambar 4. Tampilan Output Admin Halaman Berita

5. Tampilan Input Admin Halaman Keahlian

Tampilan input halaman keahlian digunakan oleh admin untuk menginput data pada halaman keahlian, berikut tampilannya.

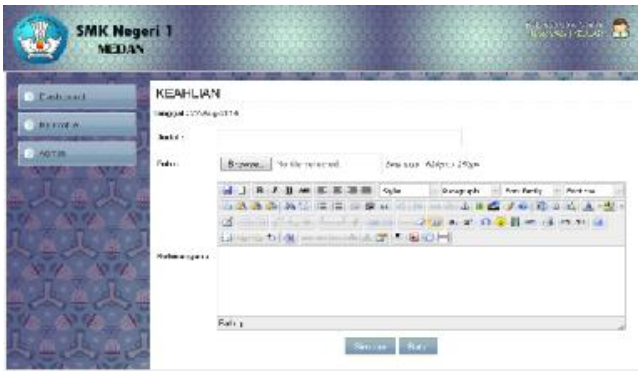

Gambar 5. Tampilan Input Admin Halaman Keahlian

6. Tampilan Output Admin Halaman Keahlian

Tampilan output halaman keahlian digunakan oleh admin untuk menampilkan data pada halaman keahlian, berikut tampilannya. 


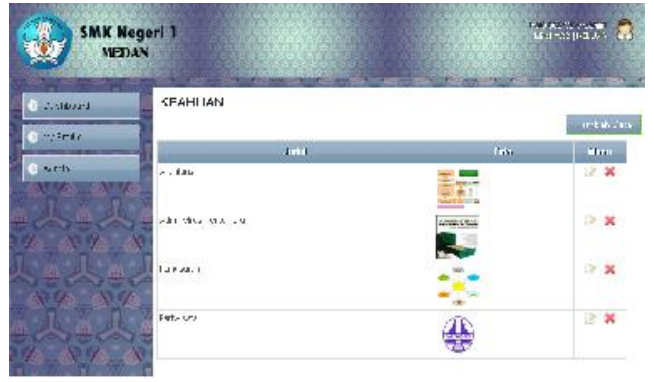

Gambar 6. Tampilan Output Admin Halaman Keahlian

7. Tampilan Input Admin Halaman About

Tampilan input halaman about digunakan oleh admin untuk menginput data pada halaman about, berikut tampilannya.

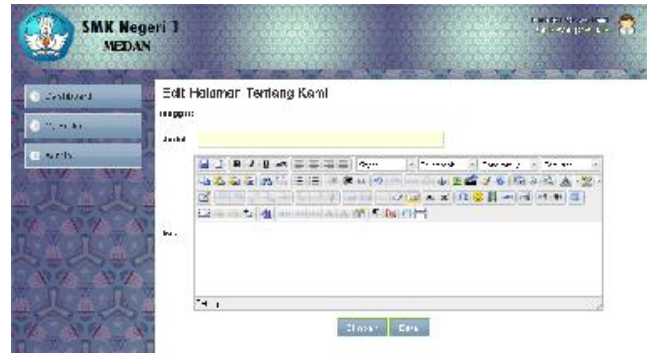

Gambar 7. Tampilan Input Admin Halaman About

8. Tampilan Output Admin Halaman About

Tampilan output halaman about digunakan oleh admin untuk menampilkan data pada halaman about, berikut tampilannya.

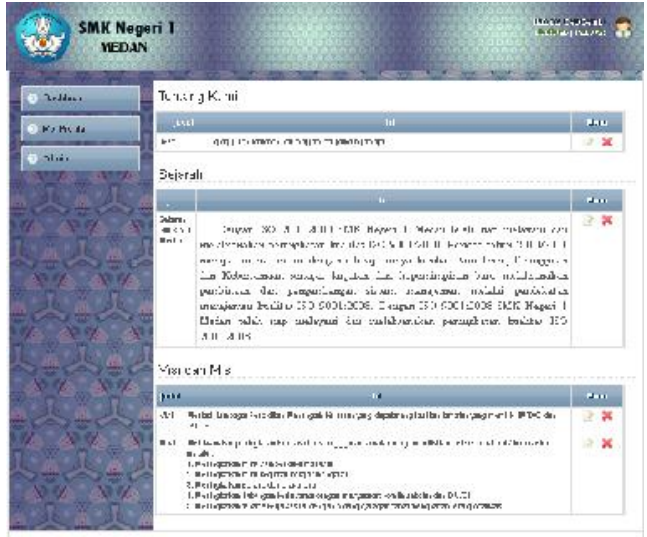

Gambar 8. Tampilan Output Admin Halaman About

\section{KESIMPULAN}

Dari penelitian yang dilakukan dapat ditemukan suatu kesimpulan bahwa dengan perkembangan teknologi yang semakin pesat, sarana dan prasarana pendidikan pun harus mengikutinya, salah satunya dengan media komputerisasi yaitu internet. Dengan internet dimana siswa maupun guru dapat mengakses ilmu pengetahuan dan informasi kapan saja dan dimana saja. Banyak sekali manfaat dari internet. Salah satunya adalah pembuatan sistem berbasis web, sistem ini akan menampilkan informasi mengenai hal-hal sesuai dengan apa yang dikehendaki oleh pembuat. 


\section{DAFTAR PUSTAKA}

[1] Andaru, A. (2018). Pengertian database secara umum. OSF Preprints.

[2] Banjarnahor, J., \& Lim, A. X. (2020). Aplikasi Pembayaran Uang Kuliah Pada Universitas Prima Indonesia Menggunakan Metode Fuzzy Logic Berbasis Android. 2(1), 7-13.

[3] Hardiansyah. (2018). Kualitas Pelayanan Publik Konsep Dimensi Indikator dan Implementasinya. Gava Media.

[4] Nababan, M. N. K., Desyana, T., Rumapea, S., Sihotang, S. S., \& Gultom, L. M. (2020). ANDROID MENGGUNAKAN ALGORITMA AES. 3(2), 76-80.

[5] Sekip, J., Tengah, P., Petisah, K. M., Medan, K., \& Utara, S. (2020). PENERAPAN METODE FULL COSTING DALAM PENENTUAN HARGA POKOK PRODUKSI PADA PT . MEDAN TROPICAL CHANNING \& FROZEN INDUSTRIES. 2(1), 29-33.

[6] Sihombing, O., Nainggolan, N. S., Gaol, B. L., \& Kesuma, N. (2020). Rancang Bangun Aplikasi Objek Wisata Kabupaten Tapanuli Tengah Berbasis Android. 2(1), 14-17.

[7] Simarmata, J., Limbong, T., Tambunan, A. R. S., Simanjuntak, M. P., Limbong, R., Purnomo, A., Kumalasari, R. D., Anam, F., Khoifulloh, K., Nisa, K., Aryni, Y., Purba, O. N., Sianturi, F. A., Tarigan, P., \& Napitupulu, E. (2018). Multimedia of number recognition for early childhood using image object. International Journal of Engineering and Technology(UAE), 7(3.2 Special Issue 2), 796-798. https://doi.org/10.14419/ijet.v7i3.2.18760

[8] Sitanggang, D., Sihombing, N., Silalahi, L., Sirait, M. M., Teknologi, F., Komputer, I., Indonesia, U. P., Sekip, J., Tengah, P., Petisah, K. M., Medan, K., \& Utara, S. (2020). ANALISIS PERANCANGAN APLIKASI PEMESANAN TIKET KAPAL BERBASIS ANDROID. 2(1), 34-38. 